\title{
平面分布したマイクロカプセル群の数濃度と崩壊率に関する実験的解析
}

\author{
杉田 直広 ${ }^{* 1}$ ，進士 忠彦*1
}

\section{Experimental analysis of number concentration and disruption rate of two-dimensionally distributed microcapsules}

\author{
Naohiro SUGITA ${ }^{* 1}$ and Tadahiko SHINSHI*1 \\ ${ }^{* 1}$ Tokyo Institute of Technology \\ 4259 Nagatsuta-cho, Midori-ku, Yokohama-shi, Kanagawa 226-8503, Japan
}

Received: 20 May 2020; Revised: 10 October 2020; Accepted: 25 February 2021

\begin{abstract}
Disruption of gas-filled microcapsules under pulsed ultrasound irradiation is experimentally studied. The goal of this study is to evaluate the disruption rate of the polymer-shelled microcapsules as a function of the mean number concentration of the microcapsule population. In the present study, we defined the disruption of a microcapsule as decapsulation of the shell layer followed by exposure of an internal gas bubble, growing to visually detectable size through mass diffusion. An experimental setup has been designed to sonicate two-dimensionally dispersed microcapsules in a planar microchamber. Pulsed ultrasound at $1 \mathrm{MHz}$ is irradiated normal to the chamber from a planar ultrasound transducer. Pure water and glycerol aqueous solution of 30 wt. \% were used as the dispersion media. Image processing of the recorded microscopic images yields capsule size distribution and local concentration distribution defined as an inverse of the occupied area of the capsule position (Voronoi area). The mean number concentration is controlled over a wide range from 5 to 200 capsules $/ \mathrm{mm}^{2}$, while the mean capsule diameter is controlled between 25 and $40 \mu \mathrm{m}$ regardless of the concentration. The disruption rate is evaluated comparing the number of disrupted microcapsules (gas bubbles) and the total number of microcapsules in the target area of the ultrasound irradiation. The disruption rate turned out to decrease with the mean concentration and is inversely proportional to the mean concentration for the particular case of the two-dimensional spatial distribution.
\end{abstract}

Keywords : Microcapsules, Ultrasound, Shell disruption, Concentration, Size distribution, Bubble cloud dynamics

\section{1. 緒言}

生体組織への局所的な薬剂導入に利用されるドラッグデリバリーシステム（DDS）は，抗癌剤の局所的な送達 (Chowdhury et al., 2017)や特定の細胞への遺伝子導入(Lentacker et al., 2006)において重要な技術と言える. DDS で は，体内の目標位置まで薬剤を保持したまま輸送する安定性と，目標位置において薬剤を放出する制御性を兼㸚 備えた薬剤のキャリアが必要となる，超音波で薬剤の放出を制御する DDS では，マイクロカプセルがこのキャ リアの役割を果たす．内部にガス気泡を含むマイクロカプセルの場合，音波照射によるカプセル周囲の周期的な 圧力変動によって, 内部気体の体積が膨張と収縮を繰り返す振動を行う. 振動応力がカプセルの表面を覆うシェ ルに歪みを生じ，カプセルが破裂に至る。このような超音波による機械的刺激を用いて，シェル内側に薬剤を付 加したマイクロカプセルを崩壊させることによって，目標位置と目標時間において，必要な量の薬剤を血液中に 放出させることが可能となる(Ibsens et al., 2013; Wischhusen and Padilla, 2019). これにより，健全な細胞に対する薬 剤の副作用を低減する効果が期待できる.

しかしながら，血液に対する耐溶解性に優れ，液中で長時間安定に存在できるマイクロカプセルは，その機械 強度が増強してしまう傾向がある。この場合，超音波照射によって崩壊しなかったマイクロカプセルが，全身を 循環し，予期せぬ場所と時間に崩壊し，健全な細胞に対して毒性を発揮することが問題となる(Ibsen et al., 2013).

No.20-00193 [DOI:10.1299/transjsme.20-00193], J-STAGE Advance Publication date : 8 March, 2021

*1 正員, 東京工業大学 科学技術創成研究院 未来産業技術研究所（广226-8503 神奈川県横浜市緑区長津田町 4259)

E-mail of corresponding author: sugita.n.aa@m.titech.ac.jp 
したがって，薬剤による副作用を抑制しながら，目標位置の組織において，治療に必要な薬剤の取り込み量を得 るためには，照射する超音波のパラメータを適切に設定する必要がある. 強力集束超音波（HIFU）に代表される 高強度の集束超音波は，その直接的な温熱作用と，キャビテーション気泡の圧壊による機械的な作用により，健 全な細胞を損傷させる(Chowdhury et al., 2017). 標的ではない組織への副作用および損傷を最小限に抑えるために は, より低強度の超音波を用いてマイクロカプセルの崩壊確率を向上させる技術が必要である(Skachkov et al., 2014; Juang et al., 2018).

超音波に対して応答性を有する種々のマイクロカプセルは，共通して，その内部に気泡核を含む中空構造を有 する. このようなマイクロカプセルは，超音波振動子から直接照射される超音波ビーム（1 次音場）によって， その体積が膨張と収縮を繰り返す体積振動を行う。同時に，体積振動を行うマイクロカプセルは自身が音源とな り, 周囲に 2 次的な圧力波（2 次音場）を放射する.この音響放射圧を介して, 集団中の気泡またはマイクロカ プセルの体積振動は相互に干渉している. 本稿では, 2 次音場によって相互に干渉する複数のマイクロカプセル の集団をマイクロカプセル群と呼ぶ．超音波照射による崩壊挙動は，第一に表面を覆っているシェル材の機械的 性質(Borden et al., 2005; Bouakaz et al., 2005) と内包寸る気体の種類(Chatterjee et al., 2005)に依存するが, 集団内の音 響的な相互干渉の効果によっても, 崩壊挙動は大きく変化することが報告されている(Chang et al., 2001; Arora et al., 2007). 球形気泡の体積変化および音響放射による連成効果は, Plesset 型の運動方程式に基づいて数学的に記述す ることができる(Brennen, 2014; Zeravcic et al., 2011). 気液界面にシェルを有するマイクロカプセルの場合には，シ エルによる剛性と減衰の変化を記述する修正項を, 運動方程式に追加したモデルが提案されている(Faez et al, 2012). しかしながら, これらの数学モデルを用いてカプセル群の崩壊現象を予測するためには, シェルの機械強 度のばらつき(Faez et al., 2012)を同定する必要があり，大規模なカプセル群において崩壊現象の定量的な予測には 至っていない.

液中に孤立した単一のマイクロカプセルの崩壊挙動は, 光学顕微鏡を用いた高速度撮影によって可視化するこ とができる. Borden et al. (2005)は，マイクロカプセル内の気泡核の溶解と分裂現象をマイクロバブルの崩壊と定 義し, シェルを構成する脂質分子の種類によって, 超音波照射下における溶解と分裂に対する安定性が変化する ことを示した. より硬質なシェル（ポリマー）を有するカプセルの場合には，シェルの破裂とそれに続く内包ガ スの漏出がマイクロカプセルの崩壊と定義されている(Bouakaz et al., 2005; Koyama et al., 2006; Helfield et al., 2017). Koyama et al. (2006)は, 熱可塑性ポリマーのシェルの崩壊に必要な超音波音圧の閾值を実験的に求めた. DDS で 望まれる低音圧の超音波を用いた場合, マイクロカプセルの破壊は, カプセルの直径, 超音波の周波数, 音圧お よびパルス幅に依存することを報告している. しかし, 複数のマイクロカプセルが集合して存在する場合には, 崩壊率を定量的に評価した実験結果は報告されていない. マイクロカプセル群の崩壊率を光学的観察から計測す るためには，広範囲に分布した多数のマイクロカプセルを顕微鏡の同一の焦点面内に捕捉し，空間分解能を維持 したまま同時に撮影する必要がある.

一方, Chang et al. (2001)の実験は，超音波造影剤マイクロバブルの崩壊に必要な音圧の閾值が，数濃度の増加 に伴って急速に増大し, 高濃度域で飽和することを明らかにしている. Arora et al. (2007)は, 超音波造影剤マイク ロバブルを気泡核として発生したキャビテーション気泡群の崩壊時間が, 数濃度の増加とともに大きくなること を実験的に示し, 数值解析からも同様の傾向を得ている. 以上の実験による巨視的な観察結果は, 崩壊挙動の数 濃度依存性を示唆しているが, 崩壊したカプセルのサイズ分布や崩壊したカプセルの割合等の微視的な情報は得 られていない. したがって, 崩壊率をマイクロカプセル群の数濃度と関連づけ, 定量的に評価した研究が必要と 言える.

本研究では, マイクロカプセル群の崩壊率の数濃度特性を明らかにするため, 超音波照射前後のマイクロカプ セル群を光学的に可視化し, 画像解析を用いて崩壊したカプセルの割合（崩壊率）を定量的に算出寸る. 2 次元 的な可視化を可能にするため, マイクロカプセルを平面状のマイクロチャンバー内に 2 次元的に分散させる. マ イクロカプセル群の代表的な数濃度は, 画像解析により算出された局所濃度分布の平均值として定義する. 算出 した崩壊率と平均濃度との間にべき乗則を導出し, 数濃度の増加に伴う崩壊率の低下傾向を示す. カプセル分散 媒の粘性の変化が数濃度特性に与える影響を示すため, 分散媒が純水の場合と, 血液と同程度の粘性をもつグ リセリン水溶液の場合の崩壊率を比較する. 


\section{2. 実験方法}

\section{$2 \cdot 1$ マイクロカプセルの分散液}

マイクロカプセルを 2 次元平面内に拘束寸るため, 細胞数のカウントに用いられるスライド型のマイクロチャ ンバー(SD100, Nexcelom Bioscience)を用いた。 この樹脂製のスライドは，厚さ $0.8 \mathrm{~mm} の$ 基板に，厚さ $0.25 \mathrm{~mm} の$ カバーを施した構造であり，透明の観察空（チャンバー）の部分 $(19 \mathrm{~mm} \times 9 \mathrm{~mm} \times 0.1 \mathrm{~mm})$ には，観察対象の分 散液を導入するための 2 つ注入孔が設けられている. この平面状チャンバー内にマイクロカプセルの分散液を 注入し，マイクロカプセルを 2 次元的に分散させた. チャンバー内に注入したマイクロカプセルは，浮力によっ て上昇し，チャンバーの上面に接触した状態で面内方向に 2 次元的に整列する.

本実験では，純水およびグリセリン水溶液を分散媒として用い，液相の粘性が異なる 2 つのマクロカプセル

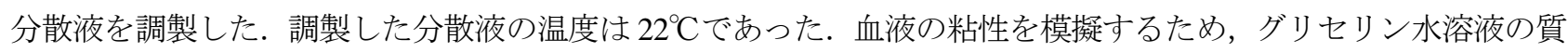

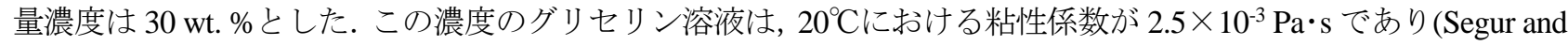
Oberstar, 1951), 同温度の純水よりも約 2.5 倍大きい．周囲流体の粘性は減衰力として働き，カプセルの振動振幅 を減少させる. マイクロカプセル（松本油脂製薬社製 F-65D）は，アクリロニトリル系共重合ポリマーのシェル を有するバルーン状の中空カプセルであり，カプセル内部には炭化水素ガスが封入されている．平均粒径および シェルの機械特性は，医療目的に用いられるマイクロバブルと異なるが，超音波照射下において凝集挙動 (Yamakoshi and Koganezawa, 2005; 江田他，2012)を示し，超音波の散乱体(Vos et al., 2007; 桝田他，2008)の役割を 果たすなど，マイクロバブルと共通の力学特性を有する．このため，超音波による薬剤放出を模擬したシェル崩 壊の実験にも用いられている(Koyama et al., 2006).

分散液中のマイクロカプセルの数濃度は，次に示寸方法で調整した．まず，粉末状のマイクロカプセルに純水 を加え，マグネティックスターラで攪拌しながら，分散液全体の体積を $V_{t o t}$ に調整した．室温における体積 $V_{t o t}$ の純水の重さ $\rho_{w} V_{t o t}$ に対して, この分散液全体の重さは $m_{t o t}$ であった. これらの重さの差から, 分散液中でマイク ロカプセルが排除している水の重さは $\rho_{w} V_{t o t}-m_{t o t}$ となる。この重さを, 純水の密度 $\rho_{w}$ で除することにより, 分散 液中でマイクロカプセルが占める体積 $V_{c}$ を算出した. これより, 分散液のカプセル部分の体積分率 (ボイド率) は，水とカプセルの占有体積の比から次式のように求めることができる.

$$
\alpha=\frac{V_{c}}{V_{t o t}}=1-\frac{m_{t o t}}{\rho_{w} V_{t o t}}
$$

ここで, $V_{t o t}=50 \mathrm{ml}, \rho_{w}=980 \mathrm{~kg} / \mathrm{m}^{3}$ とし，分散液の重さ $m_{t o t}=27.8 \mathrm{~g}$ を用いると，この分散液中のボイド率は 0.43 となる．本実験では，この体積分率を有する分散液を基準分散液と定め，基準分散液を純水で $10 \sim 100$ 倍に希釈 することによって数濃度が異なる分散液を調製した．グリセリン水溶液の分散液を調製する場合には，基準分散 液に $15 \mathrm{~g}$ のグリセリンを加え, 純水で体積を $50 \mathrm{ml}$ に調整し, 質量濃度が $30 \mathrm{wt}$. \%のグリセリン水溶液による分 散液を調製した。調製した分散液を，マイクロピペットを用いてマイクロチャンバー内に注入し，2 次元的に分 散したマイクロカプセル群の観察サンプルを得た.

\section{$2 \cdot 2$ 超音波照射}

図1(a)の示寸実験装置を用いて, マイクロチャンバーに分散したマイクロカプセル群への超音波照射を行った. 調製した分散液を導入した観察対象のチャンバーを，ポリプロピレン製のホルダーに挿入し，ホルダーとスライ ドの間に設けた $19 \mathrm{~mm} \times 9 \mathrm{~mm} \times 1 \mathrm{~mm}$ の空間に，接触媒質として脱気した純水を注入した．模式図には，ホルダ 一と脱気水の断面を表示している. 図 2(a)の点線で示したチャンバー中央部に振動子中心を合わせ，ホルダー中 心に設けた貫通穴から, 直径 $6 \mathrm{~mm}$ の超音波振動子(PW-1.0-6MM, NEPA Gene)をチャンバーに対して垂直に挿入し た．振動部の端面とスライド表面の距離が $1 \mathrm{~mm}$ となるように，スペーサを用いて振動子の軸方向位置の調節を 行った．簡単のため，図には位置調節用のスペーサや固定に必要な治具等を省略している.

信号発生器(WF1973, NF)から出力した両振幅 $5.36 \mathrm{~V}$, 周波数 $1 \mathrm{MHz}$ の正弦波パルスを, 電力増幅器(HSA4101, $\mathrm{NF})$ により 20 倍に増幅し, 超音波振動子に入力した. この正弦波パルス数を決めるために, 以下の実験を行った. 周波数 $1 \mathrm{MHz}$, 電圧両振幅 $40 \mathrm{~V}$ の連続波を振動子に入力し, 振動子端面の中心から軸方向に $3 \mathrm{~mm}$ 離れた点での 
音圧を，同じニードル型ハイドロホン(HY05N, Toray Industries)を用いて測定した．超音波振動子の音圧波形を， 水槽中で測定した場合の結果を図 1(b)に示寸.この超音波振動子は減衰が小さく, 定常な応答を示寸までに $100 \mu \mathrm{s}$ を要する. 音場が定常状態になると, 体積振動を行うカプセル間に働く引力（第 2 ビヤクネスカ）によって, 複 数のカプセルの凝集が生じると同時に, 凝集したカプセルは音響流によって解析範囲の外側に移動する. 本実験 では，カプセルの移動を最小限に抑えるため，照射する超音波のサイクル数を 100 とし，過渡的な音波照射に対 するカプセル崩壊を観察した.

\section{$2 \cdot 3$ 顕微鏡撮影と画像解析}

チャンバー内に 2 次元的に分散させたマイクロカプセルの粒径分布と局所濃度分布を求めるため, 光学顕微鏡 を用いてチャンバー全体像の撮影を行い，画像処理ソフトウェアを用いてマイクロカプセル群の粒子解析を行っ た. 分散液を注入したマイクロチャンバーを, XY 自動ステージ上に固定し, 自動ステージを水平方向に $1.08 \mathrm{~mm}$ ずつ断続的に移動させながら, 格子状にチャンバーの全体像を撮影した. マイクロスコープの露光時間を $8 \mu \mathrm{s}$ と し，八ロゲンランプ光源の透過照明を用いることにより，マイクロカプセルは図 2(a)に示すような影絵として撮 影された．撮影した合計 162 枚の画像を，画像処理ソフトウェア ImageJ/FIJI(Schindelin et al., 2012)を用いて貼り 合わせ，チャンバーの全体画像（8840×4400 pixels）を得た. 撮影された顕微鏡画像の空間解像度は $2.45 \mu \mathrm{m} / \mathrm{px}$ である.

貼り合わせた全体画像の背景の陰影を, 画像処理ソフトウェアを用いて除去した後, 図 2(b)に示寸二值化画像 に変換した. 前述の画像処理ソフトウェアの粒子解析機能を用いて, 図 2(b)における粒子を検出した. ここで, 図 3(b)のように，本実験で崩壞したマイクロカプセルの位置は，超音波振動子の直下に集中しており，振動子中 心から半径 $3 \mathrm{~mm}$ の円の内部を解析対象の領域 $S$ と定義した. 領域 $S$ て影絵として検出された粒子の面積と, 形 状中心の位置座標を求めた. 影絵の面積からマイクロカプセルの等価直径 $d$ を求め, 位置座標から次節で説明寸 るボロノイ図を用いて局所濃度を算出した．撮影画像の空間解像度と同程度の粒子は除外する必要があるため, 直径 $5 \mu \mathrm{m}$ に相当する $5 \mathrm{px}$ 以下の粒子を除外した. マイクロカプセルが凝集し, その輪郭が接触している場合に は, watershed 変換による領域分割アルゴリズム(Sennoga et al., 2015)を用いて, 接触した複数のカプセルを分離し て検出した. また, 検出した影絵の真円度が 0.7 以下の場合, この粒子も除外した. 本研究で用いた異なる数濃 度のカプセル分散液に対して，除外された粒子数の割合は，分散媒が純水の場合には平均 $2.7 \%(\mathrm{n}=24)$, グリセ リン水溶液の場合には平均 $1.0 \%(\mathrm{n}=26)$ であった.

a)

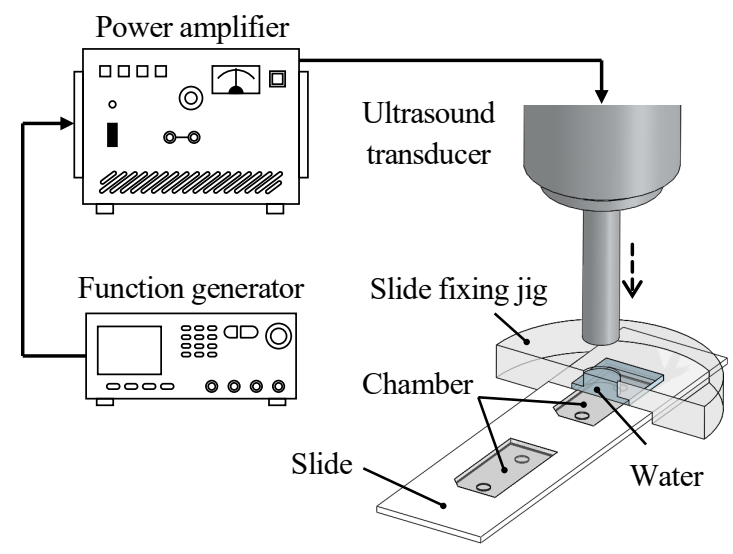

b)

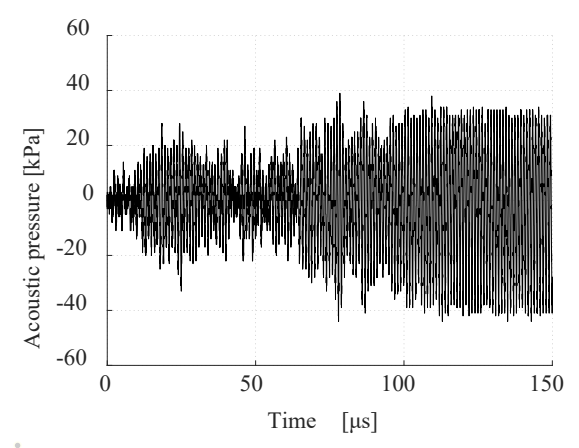

Fig. 1 (a) Schematic illustration of the experimental setup for ultrasound irradiation. For clarity, the fixing jig is shown in cross section, and the other supporting parts used to fix the slide are omitted in the illustration. (b) Pressure wave form generated by the planar ultrasound transducer driven at $40 \mathrm{~V}_{\mathrm{p}-\mathrm{p}}$ in a water container. 


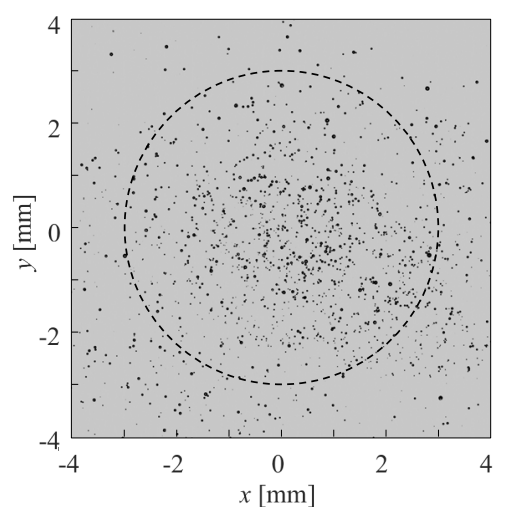

(a) Recorded image

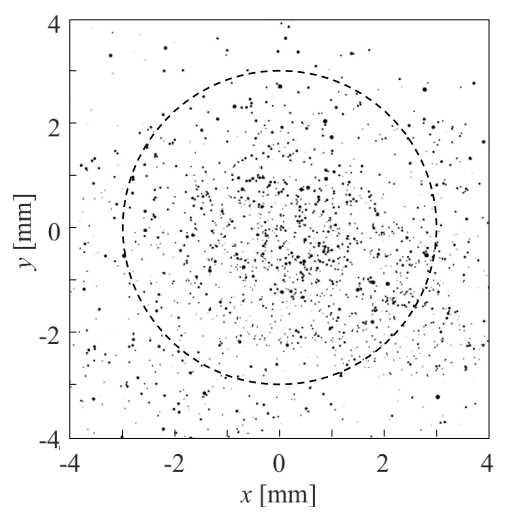

(b) Binarized image

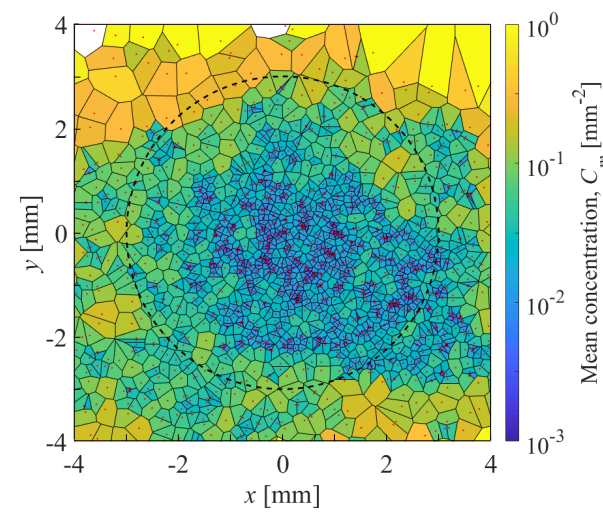

(c) Voronoi diagram

Fig. 2 (a) Recorded microscopic image and the results of image analysis; (b) binarization and (c) Voronoi diagram. The dashed circles represent the position of the ultrasound transducer. In (c), each Voronoi cell (polygonal shape) contains one microcapsule represented by a red point.

\section{$2 \cdot 4$ 局所濃度の算出}

マイクロカプセルの局所的な数濃度を求めるため, マイクロカプセルの位置座標から図 2(c)に示すボロノイ図 を作成した，ボロノイ図は，空間に分散した粒子群中のある一つの粒子位置（母点）に対して，この粒子を内包 する一つのボロノイ細胞を定義することによって構成される. ボロノイ細胞は母点を取り囲むように形成され， ある粒子に対応するボロノイ細胞内の点は，その粒子までの距離が他のどの粒子までの距離よりも小さくなる. 2 次元空間に定義されるボロノイ細胞は多角形となり，この面積をボロノイ面積という。ボロノイ面積は，一つの 粒子がその平面内で占有する面積を表しており，ボロノイ面積の逆数は，ある粒子位置における局所的な数濃度 とみなすことができる(Monchaux, 2012). したがって, マイクロカプセルの座標位置を母点とするボロノイ図から ボロノイ面積分布を求めることによって，この粒子群からなる離散的な濃度場を特徵づけることができる. 本研 究では，2 次元平面内に定義したボロノイ面積 $\mathcal{A}\left[\mathrm{mm}^{2}\right]$ の逆数を， 2 次元的に分散したマイクロカプセル群の局 所濃度 $C\left[\mathrm{~mm}^{-2}\right]$ と定義した。

\section{3. 結果と考察}

\section{$3 \cdot 1$ マイクロカプセルの崩壊挙動}

図 3 を用いて, マイクロカプセルの崩壊挙動と, 局所濃度および粒径分布の解析結果を説明する. 図 3(a)は, マイクロチャンバー内に分散したマイクロカプセルの一部である. 超音波照射によって, カプセルを覆っていた シェルが崩壊し，図 3(b)の拡大図に矢印で示すガス気泡を放出したと考えている．この例は，超音波照射から 40 分後の撮影結果である. 本実験で用いた超音波パルスの強度（約 $0.03 \mathrm{~W} / \mathrm{cm}^{2}$ ) は小さく, 脱気水中に含まれる溶 存ガスは音波照射によって析出しない.さらに，音圧 $30 \mathrm{kPa}$ の連続波を仮定すると，100 $\mu \mathrm{s}$ 間に照射領域 $S(0.28$ $\left.\mathrm{cm}^{2}\right)$ に与えられる音響エネルギーはおよそ $1 \mu \mathrm{J}$ 程度であることから, 音波照射による液体の温度上昇は無視で きる.

露出したガス気泡は, 気液界面における物質拡散によって図 4(a)のように成長した. 露出した 25 個のガス気泡 の内，崩壊直後の大きさが最大および最小のものを含む代表例の直径の時間変化を図 4(b)に示す.超音波の照射 後，カプセルからガス気泡が脱離するまでに数分の時間を要することがあった，そのため，超音波の照射 1 分後 の撮影画像では検出されなかったガス気泡は，照射 5 分後からの時間変化を示している. 全ての実験において， 超音波照射から 5 分経過後に新たなガス気泡は現れなかった. 超音波照射後 30 分付近で, 気泡直径がチャンバー の高さ $100 \mu \mathrm{m}$ と同等になり, チャンバーの上下面に接触する. その後, チャンバーの面内方向に 2 次元的に成 長するため, 直径が $100 \mu \mathrm{m}$ 付近で成長速度が増加している. 
音波照射直後のガス気泡径は，崩壊前のカプセル径よりも大きくなる傾向が見られた．この理由は，本実験で 用いたカプセルが，熱可塑性高分子で包久込んだ液体炭化水素の熱膨張により成形されており，平衡状態におい てシェルに引張力が作用しているためと考えられる．したがって，平衡状態において，カプセル内部気体の圧力 が静水圧よりも大きく, シェルを失って露出したガス気泡が，シェルから受けていた圧縮力が解放された分だけ 元のカプセル径よりも大きくなる. 図 4(b)に示寸ガス気泡の, 超音波照射 1 分後の平均直径は $33.9 \mu \mathrm{m}$ である.

一方, 粒子数濃度を約 $1 / 6$ に希釈した場合, 崩壊するマイクロカプセルの直径が図 4(c)に示すように大きくなっ た. この場合, 照射 1 分後における平均直径は $39.6 \mu \mathrm{m}$ であった. 以上より, 平均直径 $30 \mu \mathrm{m}$ 程度のマイクロカ プセルが崩壊したと推測される. 平均直径は分散媒が純水の場合も, 図 4 の結果と同様の傾向を示した.

図 3 の破線で示した超音波の照射領域 $S$ 内に含まれる粒子の総数を $N$, 上述のガス気泡の観察結果から計測し たマイクロカプセルの崩壊数 $n$ を用いて, 次式の崩壊率を定義する.

$$
\chi=\frac{n}{N}
$$

図 3 の例では, $N=1170, n=25$ であったため, 崩壊率は 0.021 となる. 次節以降では, マイクロカプセル群の平均 濃度 (3.2 節), 濃度を変化させた場合の崩壊率 (3.3 節) の算出結果を示し, 3.4 節において崩壊率と平均濃度の べき乗則を導出する.

a)

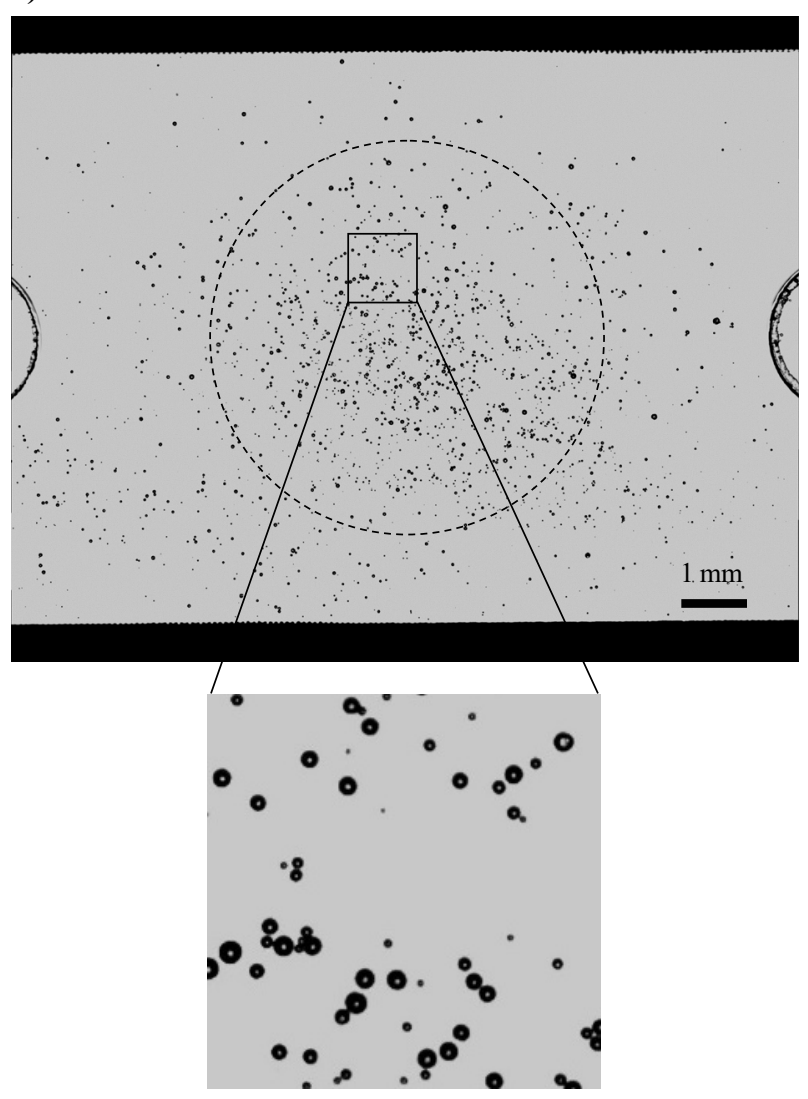

Before b)

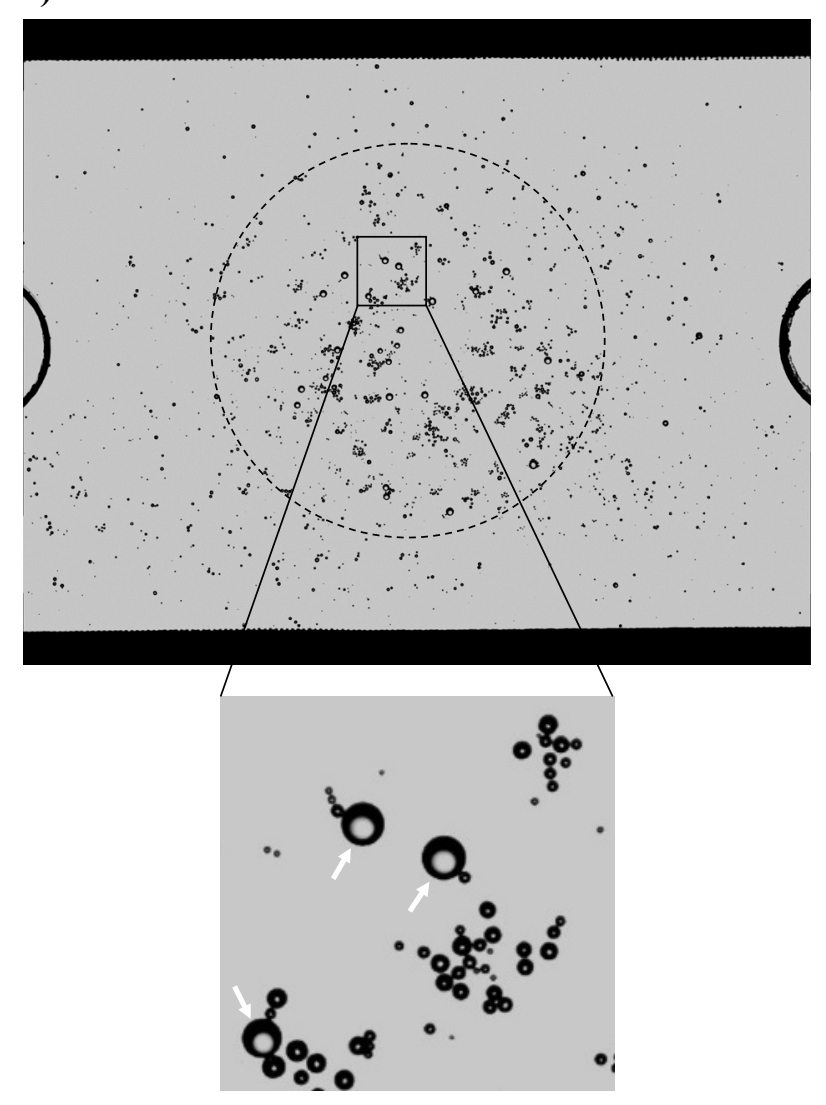

After

Fig. 3 Example of recorded microscopic images of microcapsules dispersed in glycerol aqueous solution (30 wt. \%) before (left) and 40 minutes after (right) ultrasound irradiation. Enlarged views $(1 \mathrm{~mm} \times 1 \mathrm{~mm})$ of the enclosed area denoted by squares in (a) and (b) are presented at the bottom row, where disrupted microcapsules (gas bubbles) are indicated by white arrows. The target area of ultrasound irradiation is shown by a dashed circle of $6 \mathrm{~mm}$ in diameter. The scale bar presents $1 \mathrm{~mm}$. 
a)

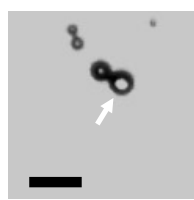

0 min

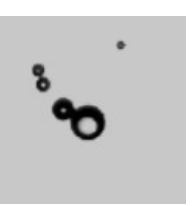

5 min

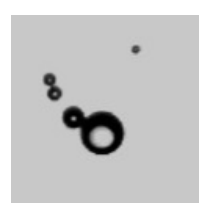

$10 \mathrm{~min}$

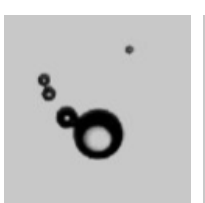

$15 \mathrm{~min}$

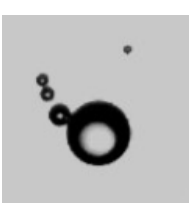

$30 \mathrm{~min}$

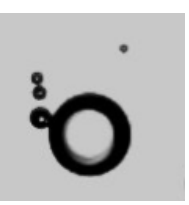

$60 \mathrm{~min}$ b)

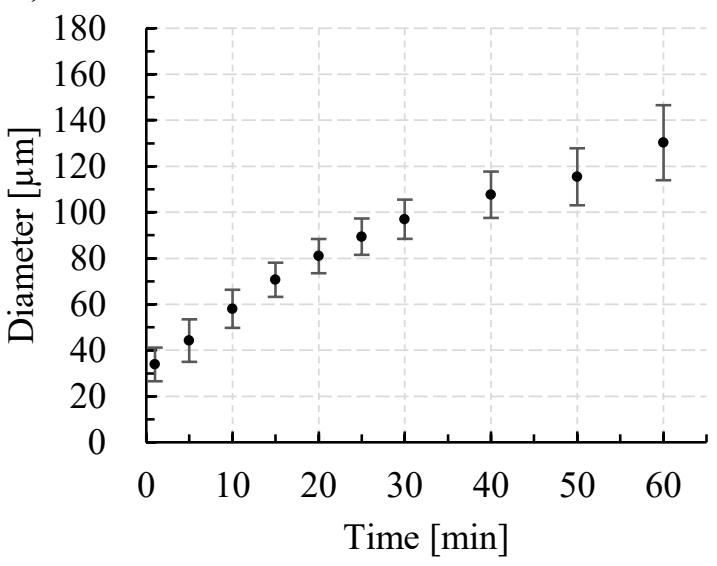

Moderate concentration $\left(C_{m}=56 \mathrm{~mm}^{-2}\right)$ c)

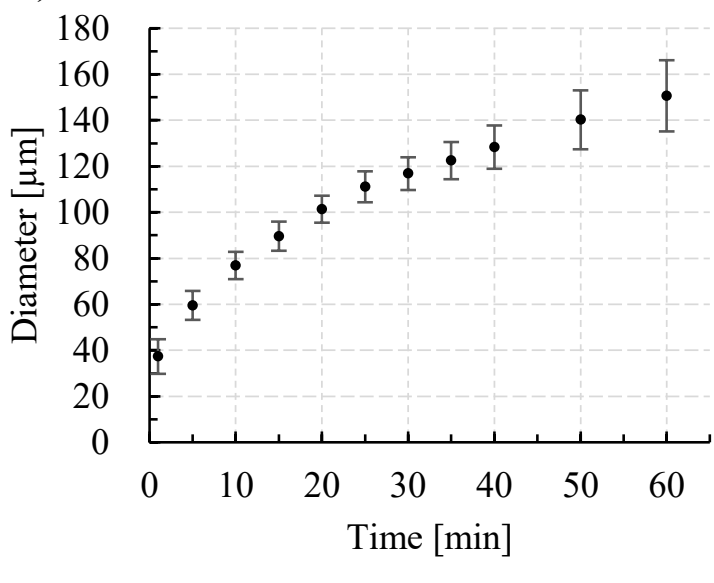

Low concentration $\left(C_{m}=9.5 \mathrm{~mm}^{-2}\right)$

Fig. 4 (a) Growth of a gas bubble decapsulated from a disrupted microcapsule shell in the $30 \mathrm{wt}$ \% glycerol aqueous solution. The scale bar presents $100 \mu \mathrm{m}$. (b-c) Temporal evolution of the gas-bubble diameters after ultrasound irradiation for (b) moderate $\left(C_{m}=56 \mathrm{~mm}^{-2}\right)$ and (c) low $\left(C_{m}=9.5 \mathrm{~mm}^{-2}\right)$ geometric mean number concentration. The bubble diameter averaged over all samples is plotted and the error bar represents the standard deviation. The growth rates change when the bubbles contact to the chamber wall. The height of the microchamber is $100 \mu \mathrm{m}$.

\section{$3 \cdot 2$ 平均濃度と平均粒径}

図 5(a)に超音波照射前の局所濃度の度数分布を示す. 図中の実線は，対数正規分布の近似曲線である. 局所数 濃度の度数分布は, 近似曲線との比較から, 左側に傾いた非対称となっており, 最頻值 $\left(29 \mathrm{~mm}^{-2}\right)$, 中央值 $\left(55 \mathrm{~mm}^{-2}\right)$ および平均值 $\left(76 \mathrm{~mm}^{-2}\right)$ が一致しないという特徵を有する。対数正規分布は，生体細胞のサイズ分布，物質の濃 度が関係する分布(橋本他，2015)などに多く見られ，その確率変数の対数值が正規分布に従う. 対数正規分布に 従う確率変数の算術平均は，分布の非対称性により実際の期待值よりも大きな值となるため，分布の特徵を表現 する要約量に適さないことが知られている.このため，局所濃度の対数值が正規分布に従うと仮定し， $\log C_{i}$ 算 術平均 $\mu_{C}$ と標準偏差 $\sigma_{C}$ を求め, この 2 つの゚ラメータを用いて局所濃度の平均濃度 $C_{m}$ を定義した.

$$
\begin{aligned}
\mu_{C} & =\frac{1}{N} \sum_{i=1}^{N} \log C_{i} \\
\sigma_{C} & =\sqrt{\frac{1}{N-1} \sum_{i=1}^{N}\left(\log C_{i}-\mu_{C}\right)^{2}}
\end{aligned}
$$

$\mu_{C}, \sigma_{C}$ は対数值 $\log C_{i}$ の算術平均および標準偏差であり，これらのパラメータを指数変換し，再び元のスケール に戻した $\exp \left(\mu_{C}\right), \exp \left(\sigma_{C}\right)$ をそれぞれ幾何平均 (geometric mean), 幾何標準偏差 (geometric standard deviation) と 呼ぶ. 幾何平均は対数正規分布の中央值に一致し, $\exp \left(\mu_{C} \pm \sigma_{C}\right)$ の範囲にサンプルサイズの $68 \%$ のデータが含まれ る. 本研究では, 幾何平均をマイクロカプセル群の平均濃度 $C_{m}$ と定義した. 


$$
C_{m}=\exp \left(\mu_{C}\right)
$$

平均濃度 $C_{m}$ は 2 次元マイクロチャンバーの単位面積に含まれるカプセル数の代表值を表している. チャンバー の高さが $0.1 \mathrm{~mm}$ であることから， $C_{m}$ を単位体積当たりの数濃度に換算すると, 平均濃度 $C_{m}=100 \mathrm{~mm}^{-2}$ は $10^{6}$ capsules/ml に相当する.

粒径分布も同様に，図 5(b)に示した度数分布の幾何平均 $\exp \left(\mu_{d}\right)$ を平均粒径 $d_{m}$ と定義した. 平均濃度 $C_{m}$ を変化 させた場合の粒径分布を図 6 に示す．図中のプロット（黒○，赤 $\square ） は ， C_{m}$ と同様に幾何平均によって定義され た平均粒径 $d_{m}$, エラーバーはその幾何標準偏差である. 平均濃度は純水の場合に $C_{m}=8 \sim 184 \mathrm{~mm}^{-2}$, グリセリン 水溶液の場合に $C_{m}=5 \sim 193 \mathrm{~mm}^{-2}$ のように数十倍のオーダーで変化させた. 平均粒径 $d_{m}$ の算術平均値は, 純水の 場合に $d_{m}=31 \pm 3 \mu \mathrm{m} \quad(n=24)$, グリセリンの場合 $d_{m}=30 \pm 2 \mu \mathrm{m} \quad(n=26)$ となり，平均濃度を大きく変化させても 平均粒径は約 $30 \mu \mathrm{m}$ にコントロールされている.

a)

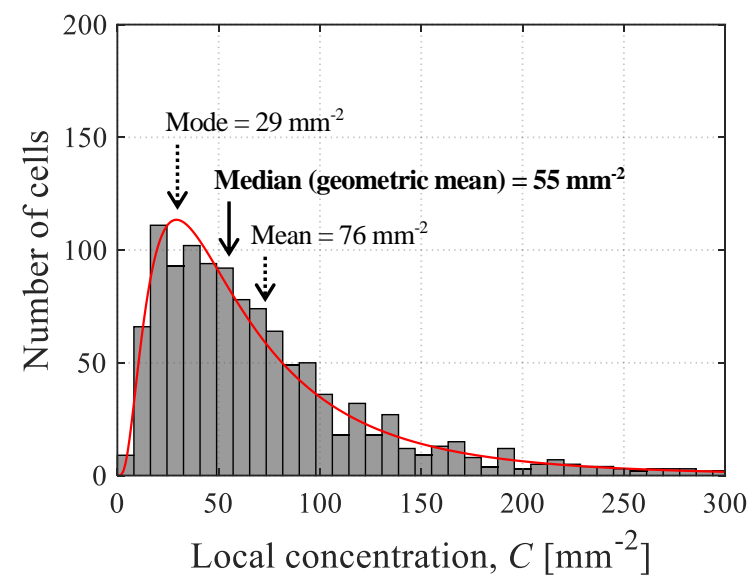

b)

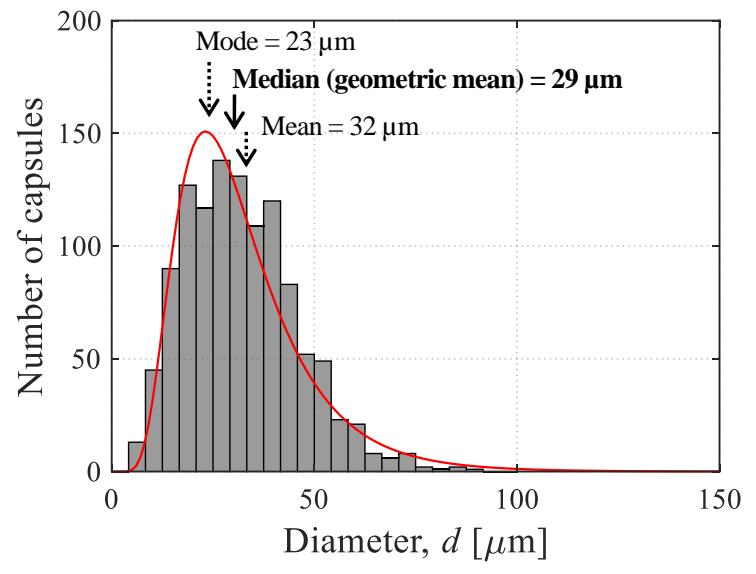

Fig. 5 Frequency distribution of (a) local number concentration and (b) capsule diameter of the sample distribution shown in Fig. 3(a) (before ultrasound irradiation). Red solid lines are lognormal fittings. The geometric mean concentration and the geometric mean diameter are $C_{m}=55 \mathrm{~mm}^{-2}$ and $d_{m}=29 \mu \mathrm{m}$, respectively.

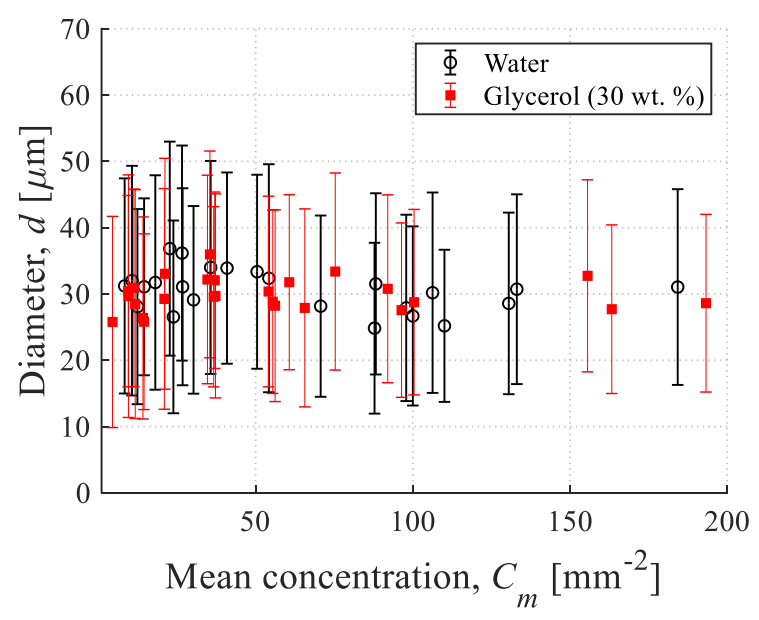

Fig. 6 Diameter distribution of two-dimensionally dispersed microcapsules in water and glycerol aqueous solution (30 wt. \%) as a function of the mean concentration. Circle and square plots are the geometric mean diameter. The error bars present geometric standard deviations. 


\section{$3 \cdot 3$ 崩壊率}

前節で求めた平均濃度に対して, 式(2)で定義した崩壊率は図 7(a)のように変化した。崩壊率は低濃度のときに 最大となり，濃度上昇とともに単調に低下した。この傾向は，分散媒が純水・グリセリン水溶液のどちらの場合 にも共通して認められた. ここで，照射領域 $S$ に含まれるマイクロカプセルの総数 $N$ は，図 7(b)に示すように， 平均濃度に対して線形的に増加している，したがって，マイクロカプセルの崩壊率は，濃度増加に対して加速的 に低下したと結論づけられる。この理由は，崩壊したカプセル数 $n=\chi N$ が，濃度に比例して増加せず，同程度に なったためである. 実際に, 図 7(c-e)に示した 3 つの平均濃度に対して, 観測されたガス気泡の数濃度が同程度 になっている，分散媒がグリセリン水溶液の場合, 液体粘性の増加によりカプセルの高次振動モードの減衰が増 大寸るため(Hilgenfeldt et al., 1996), シェルのせん断変形を伴う振動が抑制される. このため, シェルに生じる亀 裂などの進展速度が減少し, 純水の場合よりも崩壊率が低下していると推察される. 平均濃度が中程度 $(25 \sim 100$ $\left.\mathrm{mm}^{-2}\right)$ の場合には，崩壊率が極端に小さくなることがあり，純水と比較して崩壊率のばらつきが大きくなった. この理由は，シェルの損傷の程度が小さ過ぎる場合には，ガス気泡を外部に放出しないカプセルの割合が増加す るためと考えている.

a)

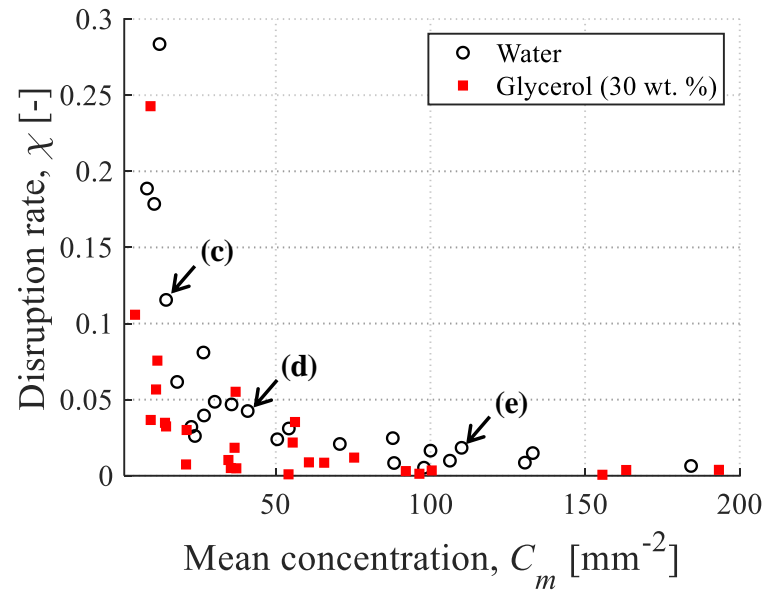

b)

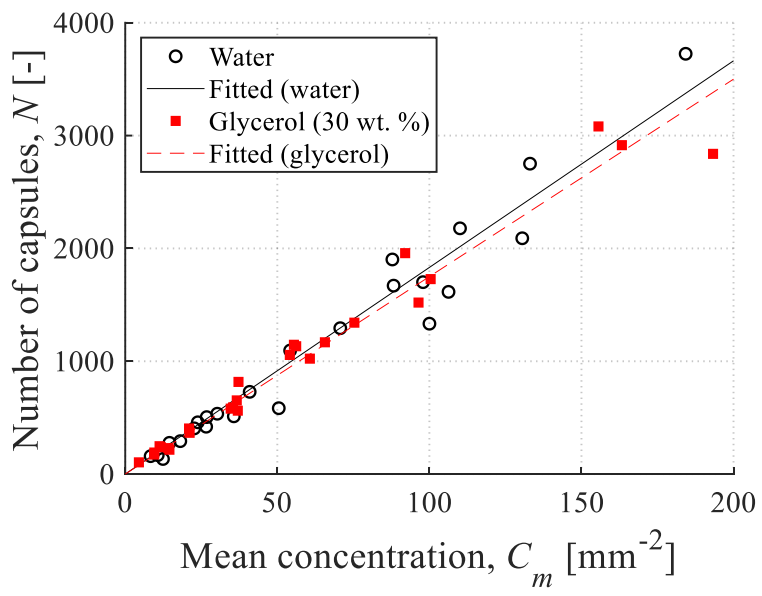

e)

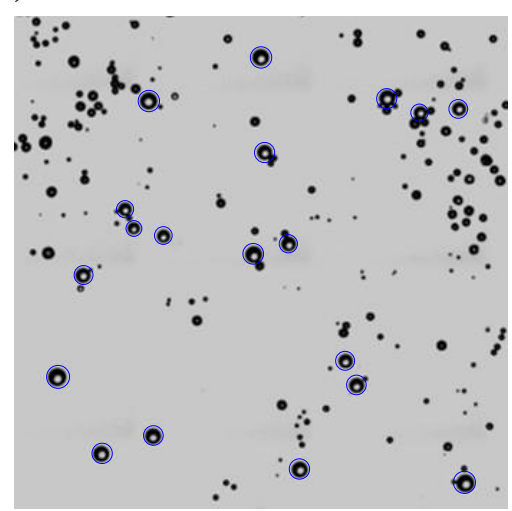

$C_{m}=41 \mathrm{~mm}^{-2}$

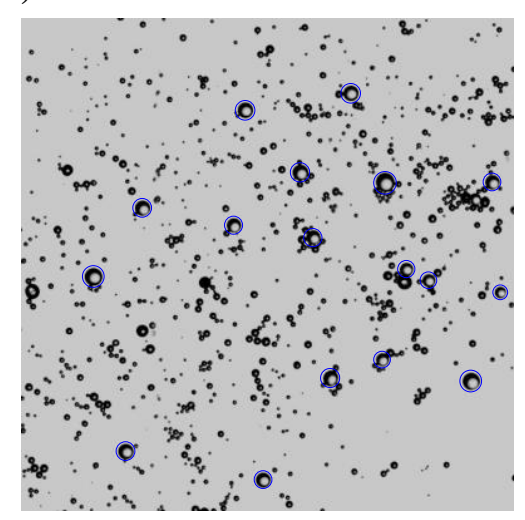

$C_{m}=110 \mathrm{~mm}^{-2}$

Fig. 7 (a) Disruption rate defined as a ratio of the number of disrupted capsules (gas bubbles), $n$, and the total number of capsules, $N$. (b) Total number of capsules in the target area (6 mm in diameter) of ultrasound irradiation. The solid and dashed lines are linear approximation of the measurements for water and glycerol aqueous solution, respectively. (c-e) Comparison of the number of disrupted microcapsules for different mean concentrations. The decapsulated capsules (gas bubbles) are indicated by blue circles. The scale bar in (c) represents $1 \mathrm{~mm}$. 


\section{$3 \cdot 4$ 平均濃度と崩壊率のべき乗則}

前節では, 濃度増加に伴って崩壊率が指数的に低下寸ることを示した. 本節では, 崩壊率と平均濃度の間にべ き乗則を仮定し，崩壊率の低下指数を定量的に考察する．音響放射圧による気泡間の相互作用は，気泡の代表径 と気泡間距離の比によって変化するため(Zeravcic et al., 2011; Sugita and Sugiura, 2017), 平均粒径 $d_{m}$ によって規格 化した平均濃度を次式のように定義する。

$$
C^{*}=\pi\left(\frac{d_{m}}{2}\right)^{2} C_{m}
$$

$C^{*}$ はカプセル自身の大きさとカプセルの占有面積との比を表し，その定義から 1 以下の值をとる無次元の数濃度 である. 崩壊率が無次元濃度の $\beta_{1}$ 乗に比例するとき, 二つの変数の対数值の間に次式の関係が成り立つ.

$$
\log \chi=\beta_{0}+\beta_{1} \log C^{*}
$$

ここで, $\beta_{0}$ は $C^{*} \rightarrow 0$ の極限における崩壊率を意味する比例係数, $\beta_{1}$ は濃度増加に対する崩壊率の変化を表す低下 指数である. 図7(a)に示したデータ点列の対数值に対して, 最小二乗法による線形近似を行い, パラメータ $\beta_{0} お$ よび $\beta_{1}$ を推定した．推定結果とその適合度を表す決定係数を表 1 に示す．両分散媒に対する決定係数は，それぞ れ 0.81 (純水) および 0.62 (グリセリン) であり, 図 8 に示した近似直線と実験結果との比較からも, 無次元濃 度と崩壊率の間に心゙き乗則が認められる. さらに, 低下指数 $\beta_{1}$ は両分散媒ともに約 -1.1 であったことから, 液体 粘性に依らず平均濃度に反比例する崩壊率の低下傾向が示された。

同定したべき乗則に基づいて, 崩壊数 $n$ の濃度依存性を考察するため, 図 7(b)に示した平均濃度とカプセル総 数の線形関係から次式の関係を仮定する.

$$
N=S C_{m}
$$

$S$ は平均濃度 $C_{m}$ で分散しているマイクロカプセル群が分布する実効的な面積であり, 図 7(b)に示した近似直線の 傾きに相当する. 式(7)および崩壊率の定義式である式(2)を, 式(6)に代入することにより, 崩壞数 $n$ は無次元濃度 の関数として次式で与えられる.

$$
n=n_{0} C^{* \beta_{1}+1}
$$

ここで, $n_{0}$ は群集を形成していない孤立したマイクロカプセルの崩壊率を表寸量であり, 次式で与えられる.

$$
n_{0}=\frac{4 S \exp \left(\beta_{0}\right)}{\pi d_{m}^{2}}
$$

$\beta_{0}$ は崩壊の閾值に関係する係数であり，シェル材の機械特性，超音波パラメータ（周波数，音圧，パルス幅）に 加え, マイクロカプセル周囲の音響的な境界条件に依存して変化する. 表 1 の推定值より, 本実験で用いた超音 波の照射条件では, $30 \mathrm{wt}$. \%質量濃度のグリセリン水溶液中における崩壊数が, 純水中の場合の約 0.32 倍に低下 したと見積もられる. 分散液の粘性は崩壊率の低下傾向に影響せず, 崩壊するカプセル数 $n_{0}$ のみを低下させたと 言える. すなわち，低下指数 $\beta_{1}$ は，音響放射を介したカプセル間の相互作用によって決まり，分散媒の液体粘性 に依らない. 低下指数が分散媒によらず $\beta_{1} \approx-1$ であったことから, 本研究の実験環境において期待される崩壊数 は次式で与えられる.

$$
n \approx n_{0}
$$

すなわち, 式(10)は崩壊数が平均濃度に依らず一定值になることを意味しており, この傾向は, 図 7(c-e)に示した 結果と符合している. 
Table 1 The fitting parameters and the determination factor of the power law relationship between $\chi$ and $C^{*}$.

\begin{tabular}{cccc}
\hline \hline Dispersion medium & $\beta_{0}$ & $\beta_{1}$ & $R^{2}$ \\
\hline Water & -7.42 & -1.14 & 0.81 \\
\hline Glycerol solution & -8.55 & -1.13 & 0.62 \\
\hline
\end{tabular}

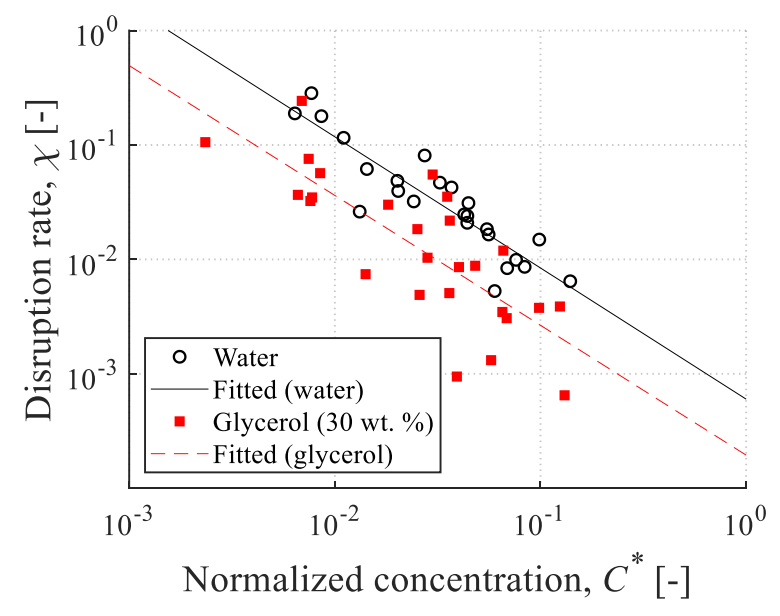

Fig. 8 Disruption rate as a function of the normalized mean concentration. Solid and dashed lines are linear approximation of the experimental results for water (circle) and glycerol dispersion (filled square), respectively.

\section{$3 \cdot 5$ 考察}

以上の結果を整理すると，次のようになる，崩壊率を維持し，崩壊せずに生き延びるカプセル数を減少させる ためには, 平均濃度を低く保つ必要がある。, 一方, 崩壊数を大きくして, マイクロカプセルからの薬剤放出量を 増加させるためには，孤立した単独のマイクロカプセルが示寸崩壊確率を向上させるしかなく，マイクロカプセ ルの濃度増加は放出量の増加に寄与しない。しかし，単に超音波音圧を増大させる，照射する超音波のパルス数 を増やすといった方法では，カプセル間に働く相互作用力によってマイクロカプセルが短時間でより高密度な凝 集体を形成し(Kotopoulis and Postema, 2010)，局所数濃度が上昇するため，崩壊率が低下し放出量が改善されない 可能性がある. したがって，高い崩壊率の下で，放出される薬剤の総量を増加させるためには，マイクロカプセ ルの数濃度を低くコントロールしながら, 超音波パルスを繰り返し照射しなければならない。この場合, 濃度コ ントロールに必要な音波音圧とその周波数に加えて(桝田他, 2008), 崩壊率の低下を最小限に抑えるための超音 波パルス数とその繰り返し周波数の探索が必要となる.

本実験の超音波パラメータの範囲では，照射音圧が崩壞率に与える影響は，分散液が純水の場合には小さく， グリセリン溶液の場合には，純水と比較して大きくなると推測される，本実験において純水を用いた場合，崩壊 によって露出したガス気泡は, 照射領域全体に分布する傾向があり, 照射位置を変化させて再度照射を行っても, 新たに崩壊するカプセル数は非常に少ない.この理由は, 純水中では周波数特性の共振点における鋭さを表す $\mathrm{Q}$ 值が比較的大きく, 共振状態にある一部のカプセルのみが小さい音圧で破壊されるためと考えられる(Koyama et al., 2006). 一方, 高粘性流体中では, 共振の Q 值が小さく応答周波数幅が大きくなるため, 音圧の変化によって 崩壊するカプセル数が変化し易くなる. 実際に, グリセリン水溶液において照射音波の音圧がより小さい場合, ある数濃度以上の高濃度領域でカプセルが崩壊しない場合がある. しかしながら, 本実験では照射平面状の音圧 分布が不明であり, 図 8 に示寸崩壊率は領域 $S$ 内の平均的な值であることに注意する必要がある. 
本研究は, 2 次元的に分布した静止状態のマイクロカプセル群を対象としており, 流動場における 3 次元的な 分布状態を考慮していない. 同じ濃度の分散液が 3 次元的に広がる場合には，隣り合うカプセルの数が奥行き方 向に増加する分, 2 次元分布よりも崩壊率の低下が増長すると予想される. さらに，共振径が広く分布する多分 散のカプセル群に対して, 照射する超音波の周波数を固定したため, 崩壊率の周波数特性を考慮できていない. 実環境において崩壊率をさらに向上させるため, 数濃度のコントロールに加えて, 粒径分布のコントロール(Segers and Versluis, 2014)によって，崩壊に関与しないカプセル径を粒径分布から除外することを検討する必要がある.

以下に，本実験に残された課題を示寸．本実験の音波照射では，ガス気泡の非定常キャビテーションは発生せ ず, カプセルの体積振動は小さい. すなわち, 崩壊率の数濃度依存性は, 線形振動を行うカプセルが発する音響 放射を介した，長距離の干渉効果(Zeravcic et al., 2011)に由来すると言える. これに対して，本実験では音波照射 前後の静的な状態（図 3）を観察しているため，カプセル間の相互作用による局所的なシェル変形の有無(Miyabe et al., 2008), これに伴う崩壊の連鎖反応といった近距離の干渉効果は明らかではない. よって, 音波照射中の力 プセルの移動量, 体積振動の振幅, 非球形振動モードの有無(Koyama et al., 2003)の定量的な可視化を行うことに よって, 近接したカプセル間の相互干渉が崩壊率に与える影響を検討する必要がある. 今後, 音波照射中の高速 度観察からカプセル崩壊挙動の時間発展を取得し, カプセル群の動的かつ大域的な崩壊のメカニズムを解明する ことが，流動場における放出制御の実現にとって不可欠となる.

\section{4. 結 言}

マイクロカプセル群の崩壊率を定量的に評価することを目的とし，超音波照射後に崩壊したマイクロカプセル を可視化するための実験方法を示し, 画像解析を用いてマイクロカプセル群の崩壊率を定量的に算出した. 本研 究では, パルス超音波の照射によって, マイクロカプセルを覆うシェルが損傷・脱離し, 内包されていたガス気 泡が露出することをマイクロカプセルの崩壞と定義した. 算出した崩壞率と平均濃度との間にべき乗則を導出し, 数濃度の増加に伴う崩壊率の低下傾向を示した. 平面状チャンバー内に 2 次元的に分散させたマイクロカプセル 群の場合, 崩壊率は分散媒の液体粘性に依らず, 数濃度のおよそ-1 乗に比例して低下寸る。この場合, 崩壊する カプセル数は数濃度に依らず同程度となる. したがって, 体内に導入するマイクロカプセルの数濃度増加は, 薬 凰放出量の増大に寄与せず，崩壊率の維持を阻害することが示唆される. 実環境において崩壊率を向上させるた めには, 3 次元流れ場においてマイクロカプセルの数濃度をリアルタイムで定量評価し, その值を低く保つ濃度 制御が必要である. したがって, 高い崩壊率の下で, 薬剤の放出量を増加させるためには, 振動振幅が小さいた めに崩壊に関与しないカプセル径の除去が不可欠と言える.

\section{謝辞}

本研究は, JSPS 科研費 $19 K 23484$ の助成を受けたものである.

\section{文献}

Arora, M., Ohl, C. D. and Lohse, D., Effect of nuclei concentration on cavitation cluster dynamics, The Journal of the Acoustical Society of America, Vol.121, No.6 (2007), pp.3432-3436.

Borden, M. A., Kruse, D. E., Caskey, C. F., Zhao, S., Dayton, P. A. and Ferrara, K. W., Influence of lipid shell physicochemical properties on ultrasound-induced microbubble destruction, IEEE transactions on ultrasonics, ferroelectrics, and frequency control, Vol.52, No.11 (2005), pp.1992-2002.

Bouakaz, A., Versluis, M. and de Jong, N., High-speed optical observations of contrast agent destruction, Ultrasound in medicine \& biology, Vol.31, No.3 (2005), pp.391-399.

Bremond, N., Arora, M., Ohl, C.D. and Lohse, D., Controlled multibubble surface cavitation, Physical review letters, Vol.96, No.22 (2006), 224501.

Brennen, C. E., Cavitation and bubble dynamics (2014), pp.30-33, Cambridge University Press.

Chang, P. P., Chen, W. S., Mourad, P. D., Poliachik, S. L. and Crum, L. A., Thresholds for inertial cavitation in albunex suspensions under pulsed ultrasound conditions, IEEE transactions on ultrasonics, ferroelectrics, and frequency control, 
Vol.48, No.1 (2001), pp.161-170.

Chatterjee, D., Jain, P. and Sarkar, K., Ultrasound-mediated destruction of contrast microbubbles used for medical imaging and drug delivery, Physics of Fluids, Vol.17, No.10 (2005), 100603.

Chowdhury, S. M., Lee, T. and Willmann, J. K., Ultrasound-guided drug delivery in cancer, Ultrasonography, Vol.36, No.3 (2017), pp.171-184.

Faez, T., Emmer, M., Kooiman, K., Versluis, M., van der Steen, A. F. and de Jong, N., 20 years of ultrasound contrast agent modeling, IEEE transactions on ultrasonics, ferroelectrics, and frequency control, Vol.60, No.1 (2012), pp.7-20.

橋本敏夫, 山田雅之, 笠井英史, 第 $\mathrm{I}$ 相試験の薬物動態解析における統計的側面一薬物動態データの分布と要約統 計量一, 計量生物学, Vol.36(Special_Issue) (2015), pp.S19-S31.

Helfield, B. L., Chen, X., Qin, B., Watkins, S. C. and Villanueva, F. S., Mechanistic insight into sonoporation with ultrasound-stimulated polymer microbubbles, Ultrasound in medicine \& biology, Vol.43, No.11 (2017), pp.2678-2689.

Hilgenfeldt, S., Lohse, D. and Brenner, M. P., Phase diagrams for sonoluminescing bubbles, Physics of fluids, Vol.8, No.11 (1996), pp.2808-2826.

Ibsen, S., Schutt, C. E. and Esener, S., Microbubble-mediated ultrasound therapy: a review of its potential in cancer treatment, Drug design, development and therapy, Vol.7, (2013), pp.375-388.

Juang, E. K., De Cock, I., Keravnou, C., Gallagher, M. K., Keller, S. B., Zheng, Y. and Averkiou, M., Engineered 3D microvascular networks for the study of ultrasound-microbubble-mediated drug delivery, Langmuir, Vol.35, No.31 (2018), pp.10128-10138.

江田廉, 渡會展之, 重原伸彦, 伊藤拓未, 南出歩, 桝田晃司, 千葉敏雄, 超音波照射による微小気泡の凝集現象解 析と赤血球の影響, 生体医工学, Vol.50, No.1 (2012), pp.138-148.

Kotopoulis, S. and Postema, M., Microfoam formation in a capillary, Ultrasonics, Vol.50, No.2 (2010), pp.260-268.

Koyama, D., Barbier, N. and Watanabe, Y., Shell effects on vibration behavior of a microcapsule in an acoustic field, Japanese journal of applied physics, Vol.42, No.10 (2003), pp.6700-6704.

Koyama, D., Osaki, A., Kiyan, W. and Watanabe, Y., Acoustic destruction of a microcapsule having a hard plastic shell, IEEE transactions on ultrasonics, ferroelectrics, and frequency control, Vol.53, No.7 (2006), pp.1314-1321.

Lentacker, I., De Geest, B. G., Vandenbroucke, R. E., Peeters, L., Demeester, J., De Smedt, S. C. and Sanders, N. N., Ultrasound-responsive polymer-coated microbubbles that bind and protect DNA, Langmuir, Vol.22, No.17 (2006), pp.7273-7278.

栘田晃司, 村松悠佑, 溝部一行, 石原謙, 超音波定在波の印加による流路中のマイクロカプセルの局所的濃度制御 とその観測, 生体医工学, Vol.46, No.2 (2008), pp.275-282.

Miyabe, J., Yoshida, K., Koyama, D. and Watanabe, Y., Destruction of the gas-filled capsule using effects of the collapsing bubble near the capsule, Journal of the Acoustical Society of America, Vol.123, No.5 (2008), pp.8270-8273.

Monchaux, R., Measuring concentration with Voronoï diagrams: the study of possible biases, New Journal of Physics, Vol.14, No.9 (2012), 095013.

Skachkov, I., Luan, Y., van der Steen, A. F., de Jong, N. and Kooiman, K., Targeted microbubble mediated sonoporation of endothelial cells in vivo, IEEE transactions on ultrasonics, ferroelectrics, and frequency control, Vol.61, No.10 (2014), pp.1661-1667.

Schindelin, J., Arganda-Carreras, I., Frise, E., Kaynig, V., Longair, M., Pietzsch, T. and Tinevez, J. Y., Fiji: an open-source platform for biological-image analysis, Nature methods, Vol.9, No.7 (2012), pp.676-682.

Segers, T. and Versluis, M., Acoustic bubble sorting for ultrasound contrast agent enrichment, Lab on a Chip, Vol.14, No.10 (2014), pp.1705-1714.

Segur, J. B. and Oberstar, H. E., Viscosity of glycerol and its aqueous solutions, Industrial \& Engineering Chemistry, Vol.43, No.9 (1951), pp.2117-2120.

Sennoga, C. A., Kanbar, E. and Bouakaz, A., An ImageJ plugin for the sizing and counting of microbubbles, 2015 IEEE International Ultrasonics Symposium (IUS) (2015), pp.1-4.

Sugita, N. and Sugiura, T., Nonlinear normal modes and localization in two bubble oscillators, Ultrasonics, Vol.74 (2017), pp.174-185.

Vos, H. J., Guidi, F., Boni, E. and Tortoli, P., Method for microbubble characterization using primary radiation force, IEEE transactions on ultrasonics, ferroelectrics, and frequency control, Vol.54, No.7 (2007), pp.1333-1345.

Wischhusen, J. and Padilla, F., Ultrasound-targeted microbubble destruction (UTMD) for localized drug delivery into tumor tissue, IRBM, Vol.40, No.1 (2019), pp.10-15. 
Yamakoshi, Y. and Koganezawa, M., Bubble manipulation by self organization of bubbles inside ultrasonic wave, Japanese journal of applied physics, Vol.44, No.6S (2005), pp.4583-4587.

Zeravcic, Z., Lohse, D. and Van Saarloos, W., Collective oscillations in bubble clouds, Journal of fluid mechanics, Vol.680 (2011), pp.114-149.

\section{References}

Arora, M., Ohl, C. D. and Lohse, D., Effect of nuclei concentration on cavitation cluster dynamics, The Journal of the Acoustical Society of America, Vol.121, No.6 (2007), pp.3432-3436.

Borden, M. A., Kruse, D. E., Caskey, C. F., Zhao, S., Dayton, P. A. and Ferrara, K. W., Influence of lipid shell physicochemical properties on ultrasound-induced microbubble destruction, IEEE transactions on ultrasonics, ferroelectrics, and frequency control, Vol.52, No.11 (2005), pp.1992-2002.

Bouakaz, A., Versluis, M. and de Jong, N., High-speed optical observations of contrast agent destruction, Ultrasound in medicine \& biology, Vol.31, No.3 (2005), pp.391-399.

Bremond, N., Arora, M., Ohl, C.D. and Lohse, D., Controlled multibubble surface cavitation, Physical review letters, Vol.96, No.22 (2006), 224501.

Brennen, C. E., Cavitation and bubble dynamics (2014), pp.30-33, Cambridge University Press.

Chang, P. P., Chen, W. S., Mourad, P. D., Poliachik, S. L. and Crum, L. A., Thresholds for inertial cavitation in albunex suspensions under pulsed ultrasound conditions, IEEE transactions on ultrasonics, ferroelectrics, and frequency control, Vol.48, No.1 (2001), pp.161-170.

Chatterjee, D., Jain, P. and Sarkar, K., Ultrasound-mediated destruction of contrast microbubbles used for medical imaging and drug delivery, Physics of Fluids, Vol.17, No.10 (2005), 100603.

Chowdhury, S. M., Lee, T. and Willmann, J. K., Ultrasound-guided drug delivery in cancer, Ultrasonography, Vol.36, No.3 (2017), pp.171-184.

Faez, T., Emmer, M., Kooiman, K., Versluis, M., van der Steen, A. F. and de Jong, N., 20 years of ultrasound contrast agent modeling, IEEE transactions on ultrasonics, ferroelectrics, and frequency control, Vol.60, No.1 (2012), pp.7-20.

Hashimoto, T., Yamada, M. and Kasai, H., Statistical aspects in the pharmacokinetic analysis of clinical phase 1 trial - the distribution and summay statistics of pharmacokinetic data-, Japanese Journal of Biometrics, Vol.36(Special_Issue) (2015), pp.S19-S31 (in Japanese).

Helfield, B. L., Chen, X., Qin, B., Watkins, S. C. and Villanueva, F. S., Mechanistic insight into sonoporation with ultrasound-stimulated polymer microbubbles, Ultrasound in medicine \& biology, Vol.43, No.11 (2017), pp.2678-2689.

Hilgenfeldt, S., Lohse, D. and Brenner, M. P., Phase diagrams for sonoluminescing bubbles, Physics of fluids, Vol.8, No.11 (1996), pp.2808-2826.

Ibsen, S., Schutt, C. E. and Esener, S., Microbubble-mediated ultrasound therapy: a review of its potential in cancer treatment, Drug design, development and therapy, Vol.7, (2013), pp.375-388.

Juang, E. K., De Cock, I., Keravnou, C., Gallagher, M. K., Keller, S. B., Zheng, Y. and Averkiou, M., Engineered 3D microvascular networks for the study of ultrasound-microbubble-mediated drug delivery, Langmuir, Vol.35, No.31 (2018), pp.10128-10138.

Koda, R., Watarai, N., Shigehara, N., Ito T., Minamide, A., Masuda, K., Kakimoto, T., Enosawa, S., Miyamoto Y. and Chiba, T., Study of aggregate formation of microbubbles under ultrasound exposure and effect with red blood cells, Transactions of Japanese Society for Medical and Biological Engineering, Vol.50, No.1 (2012), pp.138-148 (in Japanese).

Kotopoulis, S. and Postema, M., Microfoam formation in a capillary, Ultrasonics, Vol.50, No.2 (2010), pp.260-268.

Koyama, D., Barbier, N. and Watanabe, Y., Shell effects on vibration behavior of a microcapsule in an acoustic field, Japanese journal of applied physics, Vol.42, No.10 (2003), pp.6700-6704.

Koyama, D., Osaki, A., Kiyan, W. and Watanabe, Y., Acoustic destruction of a microcapsule having a hard plastic shell, IEEE transactions on ultrasonics, ferroelectrics, and frequency control, Vol.53, No.7 (2006), pp.1314-1321.

Lentacker, I., De Geest, B. G., Vandenbroucke, R. E., Peeters, L., Demeester, J., De Smedt, S. C. and Sanders, N. N., Ultrasound-responsive polymer-coated microbubbles that bind and protect DNA, Langmuir, Vol.22, No.17 (2006), pp.7273-7278.

Masuda, K., Muramatsu, Y., Mizobe, I. and Ishihara, K., Control method of local density in fluid microcapsules by acoustic 
standing wave and its monitoring, Transactions of Japanese Society for Medical and Biological Engineering, Vol.46, No.2 (2008), pp.275-282 (in Japanese).

Miyabe, J., Yoshida, K., Koyama, D. and Watanabe, Y., Destruction of the gas-filled capsule using effects of the collapsing bubble near the capsule, Journal of the Acoustical Society of America, Vol.123, No.5 (2008), pp.8270-8273.

Monchaux, R., Measuring concentration with Voronoï diagrams: the study of possible biases, New Journal of Physics, Vol.14, No.9 (2012), 095013.

Skachkov, I., Luan, Y., van der Steen, A. F., de Jong, N. and Kooiman, K., Targeted microbubble mediated sonoporation of endothelial cells in vivo, IEEE transactions on ultrasonics, ferroelectrics, and frequency control, Vol.61, No.10 (2014), pp.1661-1667.

Schindelin, J., Arganda-Carreras, I., Frise, E., Kaynig, V., Longair, M., Pietzsch, T. and Tinevez, J. Y., Fiji: an open-source platform for biological-image analysis, Nature methods, Vol.9, No.7 (2012), pp.676-682.

Segers, T. and Versluis, M., Acoustic bubble sorting for ultrasound contrast agent enrichment, Lab on a Chip, Vol.14, No.10 (2014), pp.1705-1714.

Segur, J. B. and Oberstar, H. E., Viscosity of glycerol and its aqueous solutions, Industrial \& Engineering Chemistry, Vol.43, No.9 (1951), pp.2117-2120.

Sennoga, C. A., Kanbar, E. and Bouakaz, A., An ImageJ plugin for the sizing and counting of microbubbles, 2015 IEEE International Ultrasonics Symposium (IUS) (2015), pp.1-4.

Sugita, N. and Sugiura, T., Nonlinear normal modes and localization in two bubble oscillators, Ultrasonics, Vol.74 (2017), pp.174-185.

Vos, H. J., Guidi, F., Boni, E. and Tortoli, P., Method for microbubble characterization using primary radiation force, IEEE transactions on ultrasonics, ferroelectrics, and frequency control, Vol.54, No.7 (2007), pp.1333-1345.

Wischhusen, J. and Padilla, F., Ultrasound-targeted microbubble destruction (UTMD) for localized drug delivery into tumor tissue, IRBM, Vol.40, No.1 (2019), pp.10-15.

Yamakoshi, Y. and Koganezawa, M., Bubble manipulation by self organization of bubbles inside ultrasonic wave, Japanese journal of applied physics, Vol.44, No.6S (2005), pp.4583-4587.

Zeravcic, Z., Lohse, D. and Van Saarloos, W., Collective oscillations in bubble clouds, Journal of fluid mechanics, Vol.680 (2011), pp.114-149. 